\title{
Effects of LiF on the Structure and Electrical Properties of $\left(\mathrm{Na}_{0.52} \mathrm{~K}_{0.435} \mathrm{Li}_{0.045}\right) \mathrm{Nb}_{0.87} \mathrm{Sb}_{0.08} \mathrm{Ta}_{0.05} \mathrm{O}_{3}$ Lead-Free Piezoelectric Ceramics Sintered at Low Temperatures
}

\author{
P. D. Gio*, N. D. Phong \\ Department of Physics, College of Sciences, Hue University, Hue, Vietnam \\ Email: *pdg_55@yahoo.com
}

Received 20 October 2015; accepted 10 November 2015; published 16 November 2015

Copyright (C) 2015 by authors and Scientific Research Publishing Inc.

This work is licensed under the Creative Commons Attribution International License (CC BY). http://creativecommons.org/licenses/by/4.0/

\section{(c) (;) Open Access}

\section{Abstract}

The $\left(\mathrm{Na}_{0.52} \mathrm{~K}_{0.435} \mathrm{Li}_{0.045}\right) \mathrm{Nb}_{0.87} \mathrm{Sb}_{0.08} \mathrm{Ta}_{0.05} \mathrm{O}_{3}(\mathrm{KNNLST})+\mathrm{x}$ wt\% LiF piezoelectric ceramics, where $\mathrm{x}=$ $0,2,4$, and 6 , have been fabricated successfully by the conventional solid-state reaction method. The effect of LiF on the sintering temperature, the structure and electrical properties of KNNLST ceramics was systematically studied. The LiF addition significantly reduced the sintering temperature of the ceramics from $1100^{\circ} \mathrm{C}$ to $930^{\circ} \mathrm{C}$. Experimental results showed that with the doping of LiF, all the ceramic samples could be well sintered and exhibit a dense, pure perovskite structure. With increasing LiF content, the tetragonal-orthorhombic transition point $\left(\mathrm{T}_{\mathrm{O}-\mathrm{T}}\right)$ and the Curie temperature $\left(T_{c}\right)$ of the ceramics shifted to the lower and higher temperatures, respectively. The specimens containing $4 \mathrm{wt} \% \mathrm{LiF}$ sintered at $930^{\circ} \mathrm{C}$ showed the good electrical properties: the density of $4.26 \mathrm{~g} / \mathrm{cm}^{3}$; the electromechanical coupling factor, $\mathrm{k}_{\mathrm{p}}=0.27$ and $\mathrm{k}_{\mathrm{t}}=0.40$; the dielectric constant, $\varepsilon=744$; the piezoelectric constant $\left(d_{31}\right)$ of $41 \mathrm{pC} / \mathrm{N}$.

\section{Keywords}

Lead-Free, Crystal Structure, Piezoelectric Properties, Electromechanical Coupling Factor

\section{Introduction}

Although the piezoelectric ceramic materials on the basis of PZT have the perfect physical properties and have ${ }^{*}$ Corresponding author.

How to cite this paper: Gio, P.D. and Phong, N.D. (2015) Effects of LiF on the Structure and Electrical Properties of $\left(\mathrm{Na}_{0.52} \mathrm{~K}_{0.435} \mathrm{Li}_{0.045}\right) \mathrm{Nb}_{0.87} \mathrm{Sb}_{0.08} \mathrm{Ta}_{0.05} \mathrm{O}_{3}$ Lead-Free Piezoelectric Ceramics Sintered at Low Temperatures. Journal of Materials Science and Chemical Engineering, 3, 13-20. http://dx.doi.org/10.4236/msce.2015.311003 
many important applications in science and technology such as in sensors, actuators and the other electronic devices [1]-[6], they contain large amounts of toxic lead more than $60 \mathrm{wt} \%$, their high volatilization and toxicity of $\mathrm{PbO}$ during firing process can contaminate the environment and damage human health. So, the replacement of lead by lead-free materials for piezoceramics is essential.

During recent years, intensive efforts have been made to develop lead-free piezoelectric ceramics such as Ba$\mathrm{TiO}_{3}, \mathrm{Na}_{0.5} \mathrm{Bi}_{0.5} \mathrm{TiO}_{3},\left(\mathrm{Bi}_{0.5} \mathrm{Ka}_{0.5}\right) \mathrm{TiO}_{3},(\mathrm{~K}, \mathrm{Na}) \mathrm{NbO}_{3}$, etc. [7]-[12]. Among them, (K, Na) $\mathrm{NbO}_{3}(\mathrm{KNN})$ based piezoelectric ceramics was the most interested because of its strong piezoelectric properties and high Curie temperature [7] [13]-[16]. However, the sintering temperatures of KNN based ceramics fabricated by conventional methods are quite high $\left(>1000^{\circ} \mathrm{C}\right)$, this leads to evaporation of alkaline elements during sintering process, resulting in the reduced properties of ceramics. Therefore, lowering sintering temperature of KNN based ceramics is very important.

Many researchers have successfully decreased the sintering temperature of lead-free ceramics by using the low-temperature melting additives such as $\mathrm{Bi}_{2} \mathrm{O}_{3}, \mathrm{Li}_{2} \mathrm{CO}_{3}$, $\mathrm{CuO}$, LiF, etc. [17]-[22]. In some cases, these additives can reduce easily the sintering temperature, but also reduce the piezoelectric properties of ceramics due to the appearances of second phase, or variation of structure phase [17]. Currently, the research and manufacture of ceramics material sintered at a low temperature, which leads to improvement or does not reduce the piezoelectric properties of ceramics system, is very interesting.

In this work, we present some research results on the effect of LiF on the sinterability, structure and electrical properties of $\left(\mathrm{Na}_{0.52} \mathrm{~K}_{0.435} \mathrm{Li}_{0.045}\right) \mathrm{Nb}_{0.87} \mathrm{Sb}_{0.08} \mathrm{Ta}_{0.05} \mathrm{O}_{3}$ ceramics. The LiF dopant significantly reduced the sintering temperature and enhanced the electrical properties of the ceramics at room temperature.

\section{Experimental Procedure}

The $\left(\mathrm{Na}_{0.52} \mathrm{~K}_{0.435} \mathrm{Li}_{0.045}\right) \mathrm{Nb}_{0.87} \mathrm{Sb}_{0.08} \mathrm{Ta}_{0.05} \mathrm{O}_{3}($ KNNLST $)+\mathrm{x}$ wt\% LiF ceramics, where $\mathrm{x}=0$, 2, 4 and 6, were synthesized by a conventional mixed-oxide method. Potassium carbonate $\left(\mathrm{K}_{2} \mathrm{CO}_{3}\right)$, sodium carbonate $\left(\mathrm{Na}_{2} \mathrm{CO}_{3}\right)$, lithium carbonate $\left(\mathrm{Li}_{2} \mathrm{CO}_{3}\right.$ ), and oxides $\mathrm{Sb}_{2} \mathrm{O}_{5}, \mathrm{Nb}_{2} \mathrm{O}_{5}, \mathrm{Ta}_{2} \mathrm{O}_{5}$ (purity $\geq 99 \%$ ) were used as starting materials. Mixed powder KNNLST was milled for $20 \mathrm{~h}$ with the $\mathrm{ZrO}_{2}$ balls in ethanol. Two calcinations at temperature $850^{\circ} \mathrm{C}$ for $2 \mathrm{~h}$ were then performed to obtain the single phase formation. Thereafter lithium fluoride (LiF) was mixed with the calcined KNNLST powder, and powders milled for $16 \mathrm{~h}$. The ground materials were pressed into disk $12 \mathrm{~mm}$ in diameter and $1.5 \mathrm{~mm}$ in thick under $100 \mathrm{MPa}$. To prevent the evaporation of alkaline elements, these pellets were covered by the powders with the same composition and then were sintered in a sealed alumina crucible at the temperature of $900^{\circ} \mathrm{C}, 930^{\circ} \mathrm{C}, 950^{\circ} \mathrm{C}$, and $1000^{\circ} \mathrm{C}$ for $2 \mathrm{~h}$.

The crystal structure of the sintered samples was examined by X-ray diffraction (XRD, D8 ADVANCE). The microstructure of the samples was examined by using a scanning electron microscope (SEM) (Hitachi S-4800). The densities of samples were measured by Archimedes method. The ceramic samples were polarized in silicone oil at $120^{\circ} \mathrm{C}$ by applying dc field of $30 \mathrm{kV} / \mathrm{cm}$ for $20 \mathrm{~min}$, then cooled down to room temperature under the same electric field. They were aged for $24 \mathrm{~h}$ prior to testing. The piezoelectric properties were determined by the resonance and antiresonance frequencies using an impedance analyzer (HP 4193A and RLC HIOKI 3532). Temperature dependence of dielectric constant was determined using RLC HIOKI 3532 with automatic programming; temperature of the samples was measured using Digital Multimeter 7562 . The ferroelectric property was measured by Sawyer-Tower method.

\section{Results and Discussion}

\subsection{Sintering Behavior}

Figure 1 shows the densities of KNNLST ceramics with 4 wt $\%$ LiF content as a function of sintering temperature. With increasing of sintering temperature, the density increases and reaches the maximum value $\left(4.26 \mathrm{~g} / \mathrm{cm}^{3}\right)$ at $930^{\circ} \mathrm{C}$ sintering temperature, then decreases. Meanwhile, the sintering temperature of undoped KNNLST ceramics was as high as $1100^{\circ} \mathrm{C}$, the density of $4.24 \mathrm{~g} / \mathrm{cm}^{3}$ (Table 1). Thus, the addition of LiF improved the sinterability, reduced the sintering temperature of $170^{\circ} \mathrm{C}$ compared with pure samples and increasing density of the ceramic samples. This is probable due to the formation of liquid phase of LiF. As is well known, LiF has a low melting point of $845^{\circ} \mathrm{C}$, therefore it may form liquid phase during sintering process, which could probably promote the densification behavior of KNN-based piezoceramics at reduced temperatures [17]. 


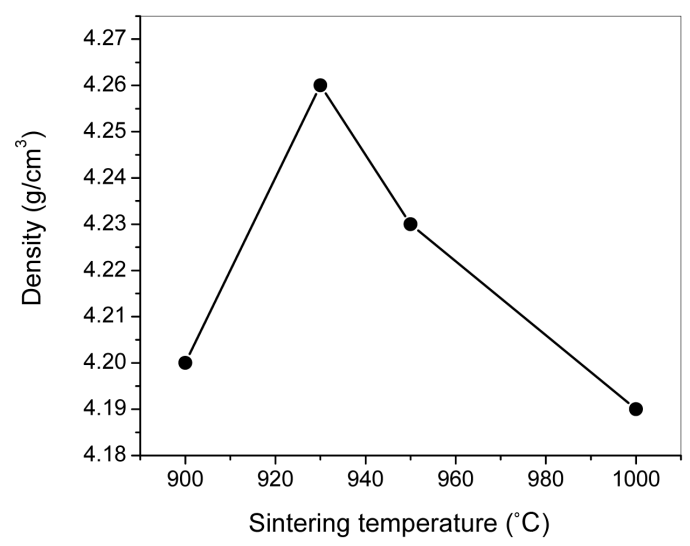

Figure 1. The density of KNNLST $+4 \mathrm{wt} \% \mathrm{LiF}$ ceramics sintered at different temperatures: $900^{\circ} \mathrm{C}, 930^{\circ} \mathrm{C}, 950^{\circ} \mathrm{C}$, and $1000^{\circ} \mathrm{C}$.

Table 1. Some properties of undoped KNNLST (sintered at $1100^{\circ} \mathrm{C}$ ) and $\mathrm{KNNLST}+4 \mathrm{wt} \% \mathrm{LiF}$ (sintered at $930^{\circ} \mathrm{C}$ ) ceramics.

\begin{tabular}{cccccc}
\hline Compositions & Sintering temperature $\left({ }^{\circ} \mathrm{C}\right)$ & Density $\left(\mathrm{g} / \mathrm{cm}^{3}\right)$ & $\mathrm{k}_{\mathrm{p}}$ & $\mathrm{k}_{\mathrm{t}}$ & $\varepsilon$ \\
\hline KNNLST & 1100 & 4.24 & 0.25 & 0.32 & 855 \\
KNNLST $+4 \mathrm{wt} \% \mathrm{LiF}$ & 930 & 4.26 & 0.27 & 0.40 & 744 \\
\hline
\end{tabular}

Figure 2 shows the planar electromechanical coupling factor $\mathrm{k}_{\mathrm{p}}, \mathrm{k}_{\mathrm{t}}$ and dielectric constant $\varepsilon$ of KNNLST +4 w\% LiF ceramics as a function of sintering temperature. The $\mathrm{k}_{\mathrm{p}}$, $\mathrm{k}_{\mathrm{t}}$ and $\varepsilon$ show similar tendency, initially they increase with the sintering temperature, reach the maximum values at $930^{\circ} \mathrm{C}$ sintering temperature, then decrease when sintering temperature exceeds $930^{\circ} \mathrm{C}$. As indicated in Table 1, for the KNNLST $+4 \mathrm{w} \% \mathrm{LiF}$ ceramics sintered at $930^{\circ} \mathrm{C}$ showed the good electrical properties, the electromechanical coupling factor $\mathrm{k}_{\mathrm{p}}$, $\mathrm{k}_{\mathrm{t}}$ are $0.27,0.40$, respectively, which were relatively higher than that pure KNNLTS ceramics. These results may be related to the suppressed volatilization of alkali elements at the low temperature sintering and the increase of density as discussed above.

From the results above, the sintering temperature for KNNLST doped LiF ceramics was selected as $930^{\circ} \mathrm{C}$.

\subsection{Structure, Microstructure and Electrical Properties}

Figure $3(\mathrm{a})$ shows the XRD patterns at room temperature with the $2 \theta$ range from $20^{\circ}$ to $70^{\circ}$ of $\mathrm{KNNLST}+\mathrm{x}$ wt $\%$ $\mathrm{LiF}$ ceramic samples sintered at $930^{\circ} \mathrm{C}$. It can be seen that all samples exhibit dominant phase structure of perovskite $\mathrm{ABO}_{3}$ type, beside a small amount of second phase $\mathrm{LiSbO}_{3}$ (PDF card \# 024-0598) and $\mathrm{K}_{6} \mathrm{Nb}_{10.8} \mathrm{O}_{30}$ (PDF card \# 070-505) have been found in pure KNNLST and KNNLST doped 2 w\% LiF samples as shown in Figure 3(a). The appearance of second phase may be due to the composition inhomogeneity of ceramics [17]. Crystal structure of the samples is modified significantly by LiF additions as shown in Figure 3(b).

Figure 3(b) shows the enlarged XRD patterns of the ceramics in the ranges of $2 \theta$ from $45^{\circ}$ to $47^{\circ}$. It is well known that KNN-based ceramics usually show orthorhombic symmetry at room temperature [14]. According to research results of the works [17] [22] [23], when the ceramics is of orthorhombic phase, the relative intensity of (002)/(020) peaks is approximately 2 and the (002) peak appears at a smaller Bragg angle, but the I(002)/I(020) decreases to 0.5 for a tetragonal phase. Therefore, from X-ray diffraction diagram in Figure 3(b) shows that likely the dominate phase in the pure KNNLST ceramics is orthorhombic, whereas the addition of LiF changes it to tetragonal symmetry. With $\mathrm{x}$ equals 4 , the ceramics shows the coexistence of two phases, and then with $\mathrm{x}=$ 6, the tetragonal phase became dominant. This result suggests that may be $\mathrm{Li}^{+}$ions are substituted for A-site of perovskite structure $\mathrm{ABO}_{3}$ which leads to the change of crystal structure from orthorhombic to tetragonal. So it could be said that the composition with $\mathrm{x}=4$ is near to the morphotropic phase boundary of KNNLST doped LiF ceramics [16].

Figure 4 shows the SEM images of the KNNLST $+x$ wt $\%$ LiF ceramics sintered at $930^{\circ} \mathrm{C}$ : (a) $\mathrm{x}=0$, (b) $\mathrm{x}=2$, (c) $x=4$ and (d) $x=6$. It can be seen that the microstructure of the pure KNNLST ceramics with square or 


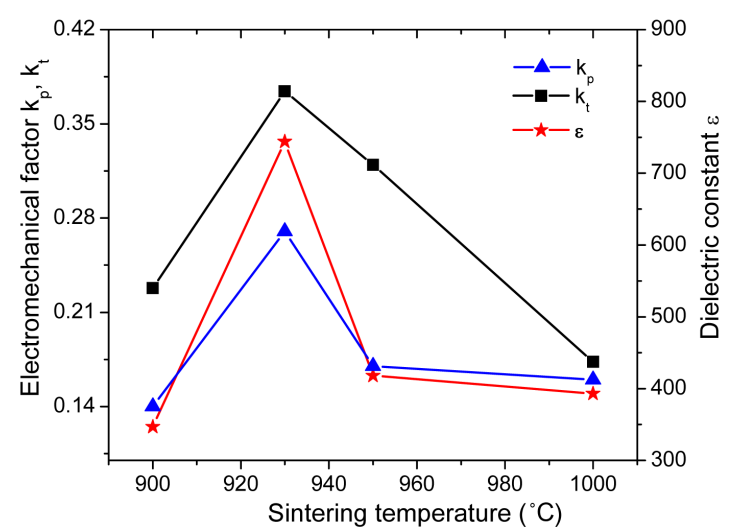

Figure 2. Electromechanical coupling factor $k_{p}, k_{t}$ and dielectric constant $\varepsilon$ of KNNLTS $+4 \mathrm{w} \% \mathrm{LiF}$ ceramics as a function of sintering temperature.

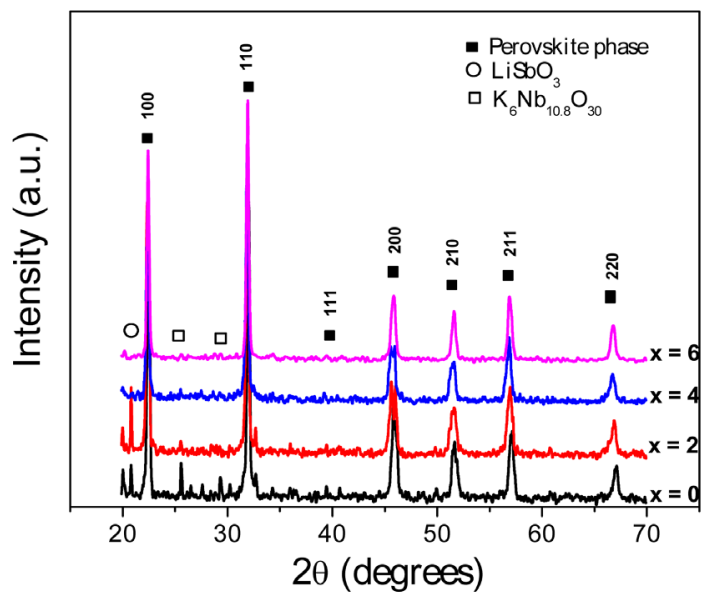

(a)

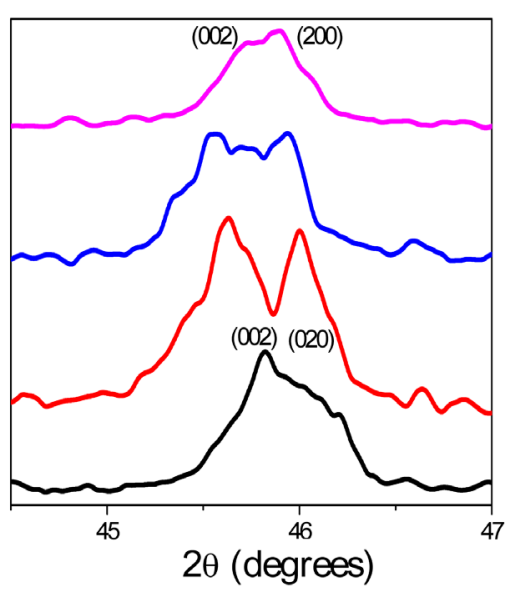

(b)

Figure 3. XRD patterns of the KNNLTS $+x$ wt $\%$ LiF ceramics (a) and enlarged region for (002)/(020) peaks of the diffraction patterns (b).

rectangular shaped grains discrete distributions, porous, not sintered materials as shown in Figure 4(a). However, the microstructure of samples becomes denser and average grain size increases from 0.4 to $2 \mu \mathrm{m}$ (shown in Table 2) as the LiF content is increased (Figures 4(b)-(d)). A homogeneous microstructure developed for the sample with $4 \mathrm{wt} \% \mathrm{LiF}$ added (Figure 2(c)). Figure 4(d) also shows that further increasing LiF content to $6 \mathrm{wt} \%$ gives rise to some large abnormal grains, porous. Such with the $4 \mathrm{wt} \% \mathrm{LiF}$ added sample, the highly dense and homogeneous microstructure was obtained, which may expect improved properties of ceramics. The grain growth with LiF addition can be explained by liquid phase sintering.

Figure 5 shows temperature dependence of dielectric constant $\varepsilon$ and dielectric loss $\tan \delta$ measured at $1 \mathrm{kHz}$ of $\mathrm{KNNLST}+\mathrm{x}$ wt $\% \mathrm{LiF}$ ceramics sintered at $930^{\circ} \mathrm{C}$. As seen in Figure 5, KNNLST doped LiF ceramics undergo two phase transition, that are the orthorhombic-tetragonal phase transition $\left(\mathrm{T}_{\mathrm{O}-\mathrm{T}}\right)$ and tetragonal-cubic phase transition $\left(\mathrm{T}_{\mathrm{C}}\right)$ during the measured temperature range [16] [17] [22] [23]. Figure 6 shows the orthorhombic-tetragonal phase transition temperature $\left(\mathrm{T}_{\mathrm{O}-\mathrm{T}}\right)$ and Curie temperature $\left(\mathrm{T}_{\mathrm{C}}\right)$ of KNNLST ceramics sintered at $930^{\circ} \mathrm{C}$ change as a function of LiF content. The pure KNNLST ceramics possess $\mathrm{T}_{\mathrm{O}-\mathrm{T}}$ and $\mathrm{T}_{\mathrm{C}}$ temperature of $67^{\circ} \mathrm{C}$ and $193^{\circ} \mathrm{C}$, respectively. With the addition of LiF, the $\mathrm{T}_{\text {O-T }}$ temperature of KNNLST ceramics decreases consistent with the analysis of XRD patterns that the phase structure of ceramics changes toward tetragonal symmetry when LiF content increases, while $\mathrm{T}_{\mathrm{C}}$ temperature increases due to diffusion of $\mathrm{Li}^{+}$into A-site of KNN lattice, showing similar tendency to the works [17] [23]. Figure 5 also shows that the dielectric loss little changes as the temperature rises from room temperature to $150^{\circ} \mathrm{C}$ and increases rapidly in the vicinity Tc.

Some physical properties of KNNLST $+\mathrm{x}$ wt $\% \mathrm{LiF}$ ceramics sintered at $930^{\circ} \mathrm{C}$ measured at room temperature 

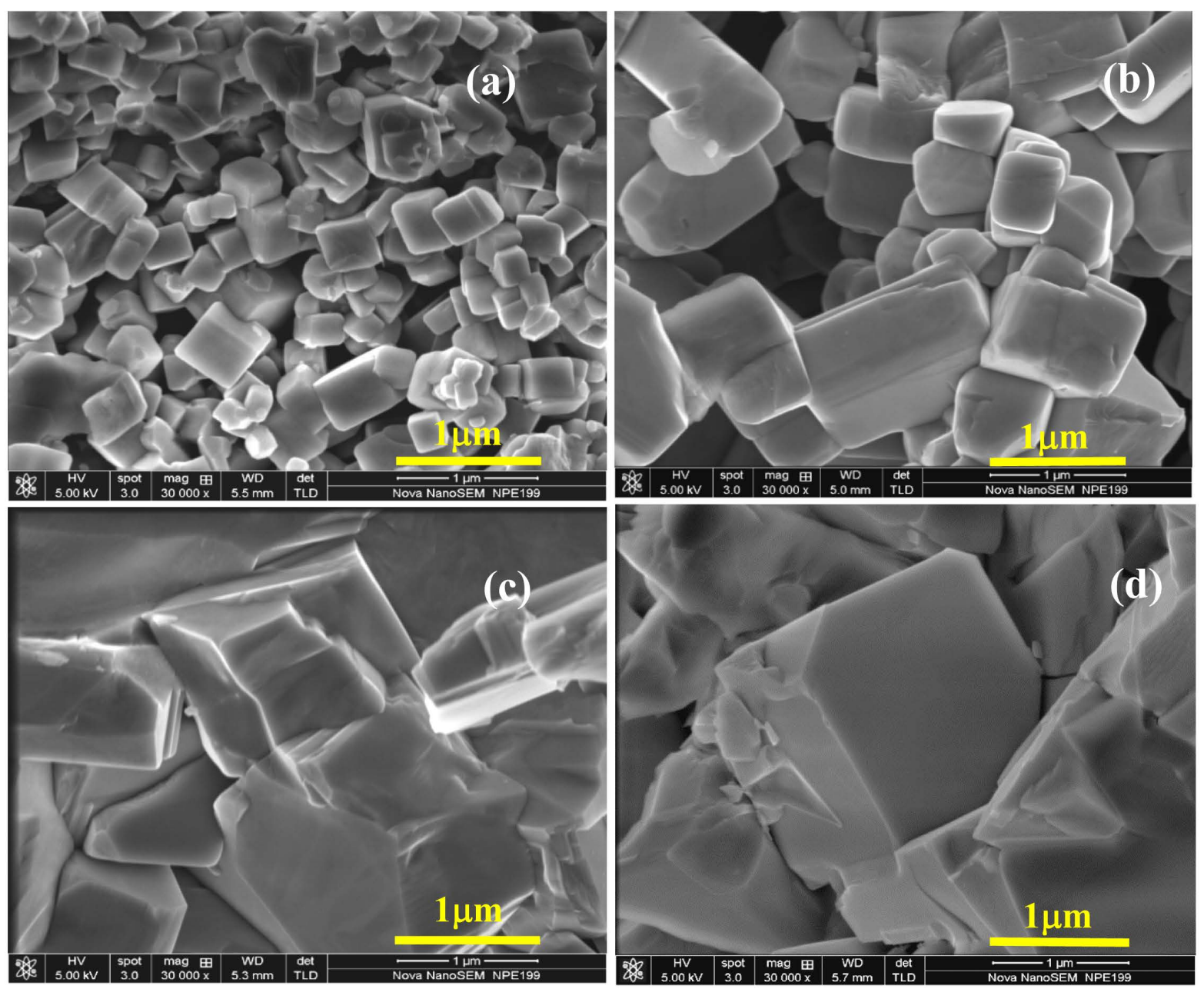

Figure 4. SEM images of KNNLST $+\mathrm{x} w \mathrm{wt} \% \mathrm{LiF}$ ceramics sintered at $930^{\circ} \mathrm{C}$ : (a) $\mathrm{x}=0$; (b) $\mathrm{x}=2 ;$ (c) $\mathrm{x}=4$; (d) $\mathrm{x}=6$.

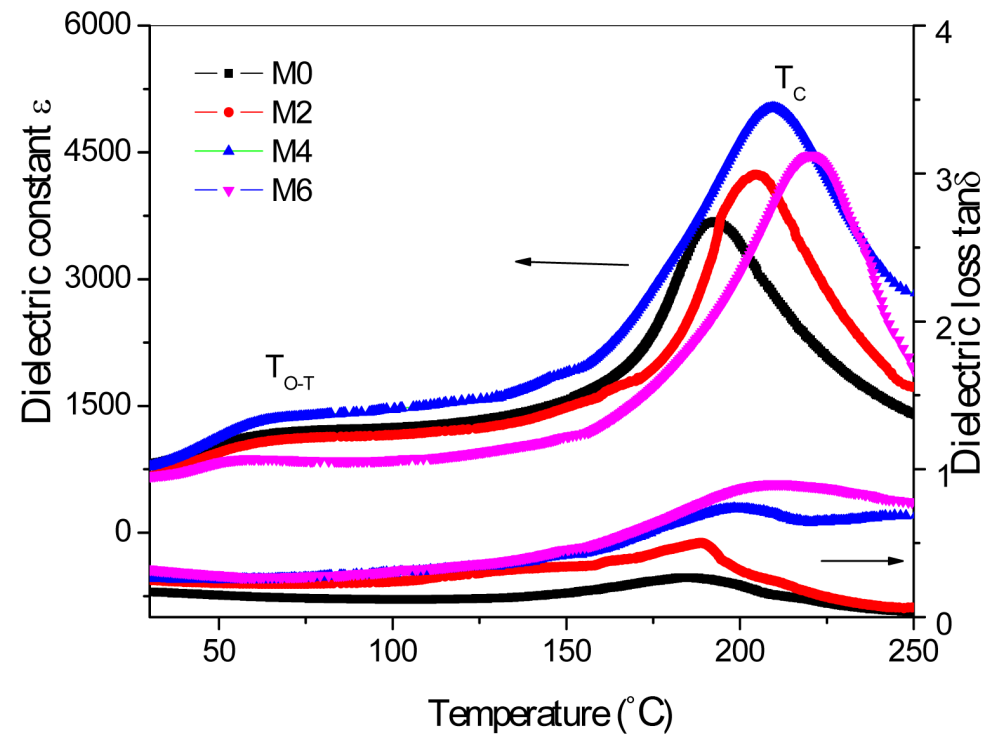

Figure 5. Temperature dependence of dielectric constant $\varepsilon$ and dielectric loss tan $\delta$ of the KNNLST $+\mathrm{x}$ wt\% LiF ceramics sintered at $930^{\circ} \mathrm{C}$. 


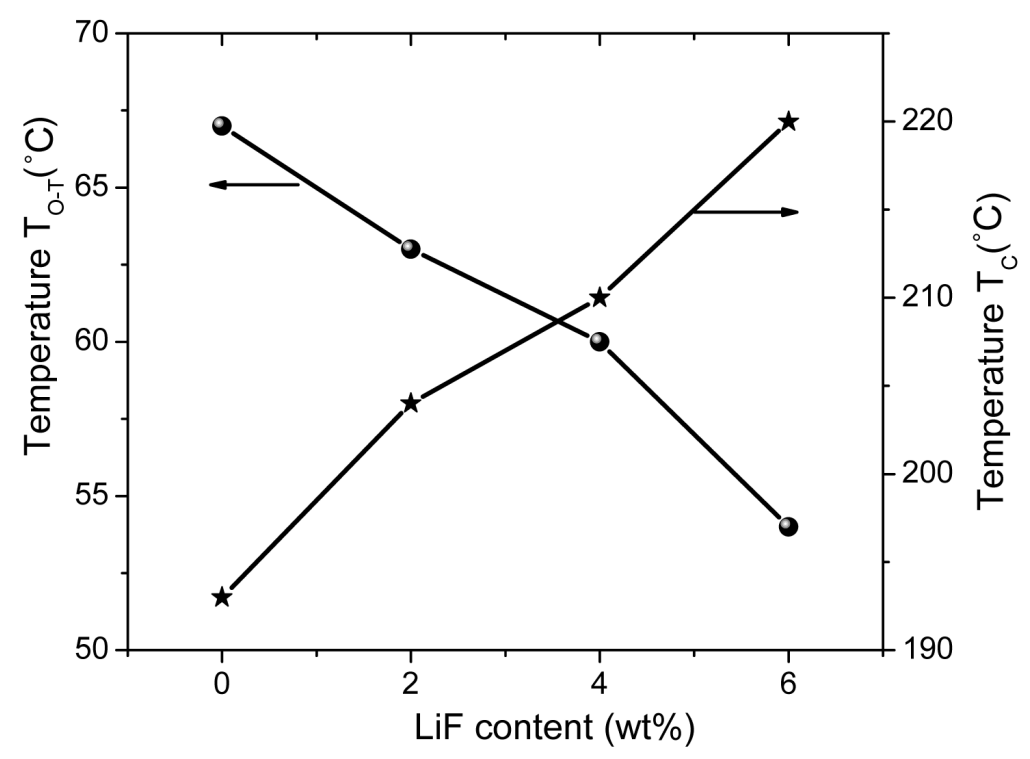

Figure 6. The orthorhombic-tetragonal phase transition temperature $\left(\mathrm{T}_{\mathrm{O}-\mathrm{T}}\right)$ and Curie temperature $\left(\mathrm{T}_{\mathrm{C}}\right)$ of KNNLST ceramics as a function of LiF content.

Table 2. Physical properties of KNNLST $+\mathrm{x} w \mathrm{t} \% \mathrm{LiF}$ ceramics sintered at $930^{\circ} \mathrm{C}$.

\begin{tabular}{ccccccc}
\hline x content & Density $\left(\mathrm{g} / \mathrm{cm}^{3}\right)$ & Average grain size $(\mu \mathrm{m})$ & $\varepsilon$ & $\mathrm{k}_{\mathrm{p}}$ & $\mathrm{k}_{\mathrm{t}}$ & \multicolumn{2}{c}{$-\mathrm{d}_{31}(\mathrm{pC} / \mathrm{N})$} \\
\hline 0 & $4.03 \pm 0.01$ & $0.4 \pm 0.15$ & 470 & 0.12 & 0.29 & 15 \\
2 & $4.15 \pm 0.01$ & $0.8 \pm 0.1$ & 577 & 0.16 & 0.36 & 23 \\
4 & $4.26 \pm 0.02$ & $1.7 \pm 0.3$ & 744 & 0.27 & 0.40 & 41 \\
6 & $4.16 \pm 0.01$ & $2.0 \pm 0.2$ & 650 & 0.17 & 0.28 & 20
\end{tabular}

also listed in Table 2. It is seen that with increasing of LiF content, the density, dielectric constant $(\varepsilon)$, planar electromechanical coupling factor $\left(\mathrm{k}_{\mathrm{p}}\right)$, $\left(\mathrm{k}_{\mathrm{t}}\right)$, piezoelectric constant $\left(\mathrm{d}_{31}\right)$ are increased. The largest values for density of $4.26 \mathrm{~g} / \mathrm{cm}^{3}, \mathrm{k}_{\mathrm{p}}$ of $0.27, \mathrm{k}_{\mathrm{t}}$ of $0.40, \mathrm{~d}_{31}$ of $41 \mathrm{pC} / \mathrm{N}, \varepsilon$ of 744 were obtained at $4 \mathrm{wt} \%$ LiF content, then decrease. These are probably related to characteristics of the density, the increasing grain size and morphotropic phase boundary effect [16].

Figure 7 shows the shape of ferroelectric hysteresis loops of the samples KNNLST+ $\mathrm{x}$ wt\% LiF measured at room temperature. From the shape of these loops, the remanent polarization $P_{r}$ and the coercive field $E_{C}$ of ceramics were determined, as shown in Figure 8. With increasing of LiF content, a sharp increases in $\mathrm{P}_{\mathrm{r}}$ was observed for samples until $x=4$, reaches the highest value $\left(11.96 \mu \mathrm{C} / \mathrm{cm}^{2}\right)$ at this content, and then decreases; while the coercive field $\mathrm{E}_{\mathrm{C}}$ strong decreases from 8.06 to $5.38 \mathrm{kV} / \mathrm{cm}$ during the measured LiF content range. These results are in good agreement with the studied dielectric and piezoelectric properties of the ceramic samples.

\section{Conclusion}

The effect of LiF addition on the sintering behavior and physical properties of

$\left(\mathrm{Na}_{0.52} \mathrm{~K}_{0.435} \mathrm{Li}_{0.045}\right) \mathrm{Nb}_{0.87} \mathrm{Sb}_{0.08} \mathrm{Ta}_{0.05} \mathrm{O}_{3}(\mathrm{KNNLST})+\mathrm{x}$ wt\% LiF $(\mathrm{x}=0 \div 6)$ ceramics was investigated. The addition of LiF improved the sinterability of the ceramics and caused an increase in the density and grain size at low sintering temperature $\left(930^{\circ} \mathrm{C}\right)$. All samples had perovskite phase structure with a change from orthorhombic to tetragonal by LiF additions and a possible morphotropic phase boundary near composition $\mathrm{x}=4$. With increasing $\mathrm{LiF}$ content, the $\mathrm{T}_{\mathrm{O}-\mathrm{T}}$ temperature of the ceramics was shifted to lower temperature, while the Curie $\mathrm{T}_{\mathrm{C}}$ temperature was shifted to higher temperature. At the LiF content of $4 \mathrm{wt} \%$, physical properties of ceramics sintered 


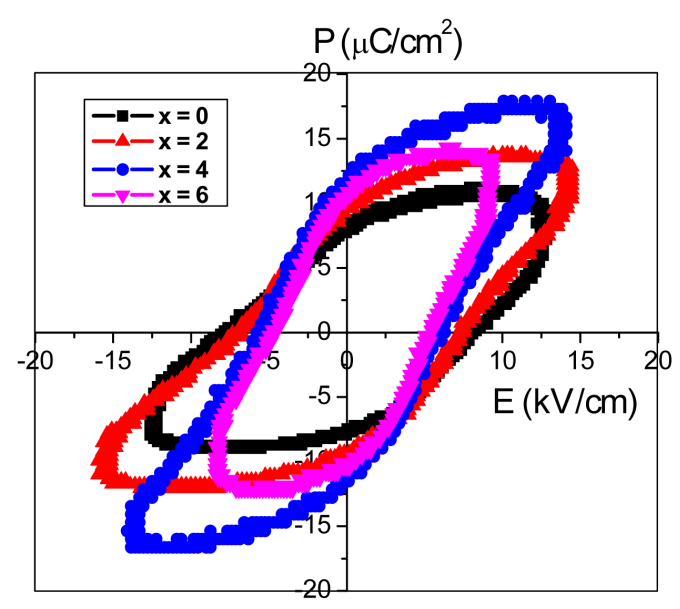

Figure 7. Hysteresis loops of KNNLTS + $\mathrm{x}$ wt\% LiF ceramic samples measured at room temperature.

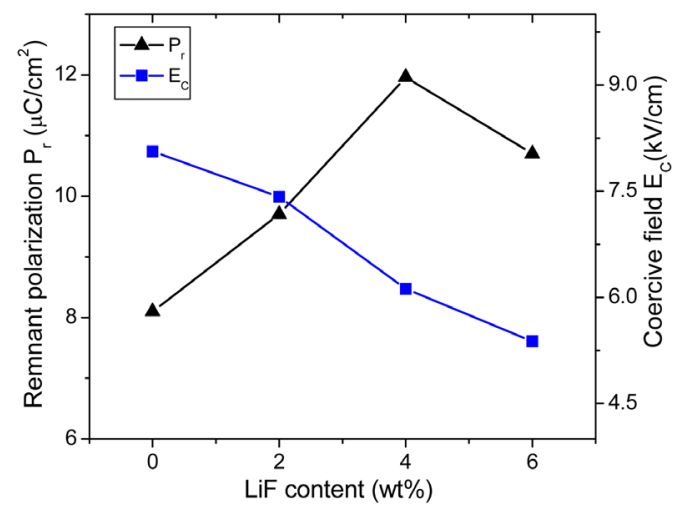

Figure 8. The remnant polarization $\left(\mathrm{P}_{\mathrm{r}}\right)$ and coercive field $\left(E_{C}\right)$ of KNNLST ceramics as a function of the LiF content.

at $930^{\circ} \mathrm{C}$ are the best.

\section{References}

[1] Xu, Y. (1991) Ferroelctric Materials and Their Applications. North-Holland, Amsterdam, London, New York and Tokyo.

[2] Hou, Y.D., Zhu, M.K., Tian, C.S. and Yan, H. (2004) Structure and Electrical Properties of PMZN-PZT Quaternary Ceramics for Piezoelectric Transformers. Sensors and Actuators A: Physical, 116, 455-460. http://dx.doi.org/10.1016/j.sna.2004.05.012

[3] Gao, F., Cheng, L., Hong, R., Liu, J., Wang, C. and Tian, C. (2009) Crystal Structure and Piezoelectric Properties of $\mathrm{xPb}\left(\mathrm{Mn}_{1 / 3} \mathrm{Nb}_{2 / 3}\right) \mathrm{O}_{3}-(0.2-\mathrm{x}) \mathrm{Pb}\left(\mathrm{Zn}_{1 / 3} \mathrm{Nb}_{2 / 3}\right) \mathrm{O}_{3}-0.8 \mathrm{~Pb}\left(\mathrm{Zr}_{0.52} \mathrm{Ti}_{0.48}\right) \mathrm{O}_{3}$ Ceramics. Ceramics International, 35, 1719-1723. http://dx.doi.org/10.1016/j.ceramint.2008.09.001

[4] Hou, Y.D., Chang, L.M., Zhu, M.K., Song, X.M. and Yan, H. (2007) Effect of $\mathrm{Li}_{2} \mathrm{CO}_{3}$ Addition on the Dielectric and Piezoelectric Responses in the Low-Temperature Sintered 0.5PZN-0.5PZT Systems. Journal of Applied Physics, 102, Article ID: 084507. http://dx.doi.org/10.1063/1.2800264

[5] Jin, B.M., Lee, D.S., Kimb, I.W., Kwon, J.H., Lee, J.S., Song, J.S. and Jeong, S.J. (2004) The Additives for Improving Piezoelectric and Ferroelectric Properties of $0.2 \mathrm{~Pb}\left(\mathrm{Mg}_{1 / 3} \mathrm{Nb}_{2 / 3}\right) \mathrm{O}_{3}-0.8\left[\mathrm{PbZrO}_{3}-\mathrm{PbTiO}_{3}\right]$ Ceramics. Ceramics International, 30, 1449-1451. http://dx.doi.org/10.1016/j.ceramint.2003.12.070

[6] Lee, J.S., Choi, M.S., Hung, N.V., Kim, Y.S., Kim, I.W., Park, E.C., Jeong, S.J. and Song, J.S. (2007) Effects of High Energy Ball-Milling on the Sintering Behavior and Piezoelectric Properties of PZT-Based Ceramics. Ceramics International, 33, 1283-1286. http://dx.doi.org/10.1016/j.ceramint.2006.04.017 
[7] Saito, Y., Takao, H., Tani, T., Nonoyama, T., Takatori, K., Homma, T., Nagaya, T. and Nakamura, M. (2004) LeadFree Piezoceramics. Nature, 432, 84-87. http://dx.doi.org/10.1038/nature03028

[8] Yeo, H.G., Sung, Y.S., Song, T.K., Cho, J.H., Kim, M.H. and Park, T.G. (2009) Donor Doping Effects on the Ferroelectric and the Piezoelectric Properties of Pb-Free $\left(\mathrm{Bi}_{0.5} \mathrm{Na}_{0.5}\right) \mathrm{TiO}_{3}$ Ceramics. Journal of Korean Physical Society, 54, 896-900. http://dx.doi.org/10.3938/jkps.54.896

[9] Abe, J., Kobune, M., Kitada, K., Yazawa, T., Masumoto, H. and Goto, T. (2007) Effects of Spark-Plasma Sintering on the Piezoelectric Properties of High-Density (1-x) $\left(\mathrm{Na}_{0.5} \mathrm{~K}_{0.5}\right) \mathrm{NbO}_{3-\mathrm{x}} \mathrm{LiTaO}_{3}$ Ceramics. Journal of Korean Physical Society, 51, 810-814. http://dx.doi.org/10.3938/jkps.51.810

[10] Song, T.K., Kim, M.-H., Sung, Y.-S., Yeo, H.-G., Lee, S.H., Jeong, S.-J. and Song, J.-S. (2007) Depolarization Temperatures in Pb-Free Piezoelectric Materials. Journal of Korean Physical Society, 51, 697-700. http://dx.doi.org/10.3938/jkps.51.697

[11] Karaki, T., Yan, K. and Adachi, M. (2007) Barium Titanate Piezoelectric Ceramics Manufactured by Two-Step Sintering. Japanese Journal of Applied Physics, 46, 7035. http://dx.doi.org/10.1143/JJAP.46.7035

[12] Karaki, T., Adachi, M. and Yan, K. (2008) High-Performance Lead-Free Barium Titanate Piezoelectric Ceramics. Advances in Science and Technology, 54, 7-12. http://dx.doi.org/10.4028/www.scientific.net/AST.54.7

[13] Wang, K., Li, J.-F. and Liu, N. (2008) Piezoelectric Properties of Low-Temperature Sintered Li-Modified (Na, K)NbO 3 Lead-Free Ceramics. Applied Physics Letters, 93, Article ID: 092904. http://dx.doi.org/10.1063/1.2977551

[14] Li, J.-F., Wang, K., Zhu, F.-Y., Cheng, L.-Q. and Yao, F.-Z. (2013), (K, Na)NbO-Based Lead-Free Piezoceramics: Fundamental Aspects, Processing Technologies, and Remaining Challenges. Journal of the American Ceramic Society, 96, 3677-3696. http://dx.doi.org/10.1111/jace.12715

[15] Eriksson, M., Yan, H.X., Nygren, M., Reece, M.J. and Shen, Z.J. (2010) Low Temperature Consolidated Lead-Free Ferroelectric Niobate Ceramics with Improved Electrical Properties. Journal of Materials Research, 25, $240-247$. http://dx.doi.org/10.1557/JMR.2010.0034

[16] Wongsaenmai, S., Ananta, S. and Yimnirun, R. (2012) Effect of Li Addition on Phase Formation Behavior and Electrical Properties of $\left(\mathrm{K}_{0.5} \mathrm{Na}_{0.5}\right) \mathrm{NbO}_{3}$ Lead Free Ceramics. Ceramics International, 38, 147-152. http://dx.doi.org/10.1016/j.ceramint.2011.06.049

[17] Zhou, J.-J., Cheng, L.-Q., Wang, K., Zhang, X.-W., Li, J.-F., Liu, H. and Fang, J.-Z. (2014) Low-Temperature Singtering of $(\mathrm{K}, \mathrm{Na}) \mathrm{NbO}_{3}$-Based Lead-Free Piezoceramics with Addition of LiF. Journal of the European Ceramics Society, 34, 1161-1167. http://dx.doi.org/10.1016/j.jeurceramsoc.2013.11.029

[18] Zhang, Y.J., Chu, R.Q., Xu, Z.J., Chen, Q., Liu, Y. and Zhang, G.C. (2012) Effects of $\mathrm{Li}_{2} \mathrm{CO}_{3}$ on the Sintering Behavior and Piezoelectric Properties of $\mathrm{Bi}_{2} \mathrm{O}_{3}$-Excess $\left(\mathrm{Bi}_{0.5} \mathrm{Na}_{0.5}\right)_{0.96} \mathrm{Ba}_{0.06} \mathrm{TiO}_{3}$ Ceramics. Current Applied Physics, 12, 204-209. http://dx.doi.org/10.1016/j.cap.2011.06.002

[19] Matsubara, M., Toshiakiamaguchi, Sakamoto, W., Kikuta, K., Yogo, T. and Hirano, S.-I. (2005) Processing and Piezoelectric Properties of Lead-Free $(\mathrm{K}, \mathrm{Na})(\mathrm{Nb}, \mathrm{Ta}) \mathrm{O}_{3}$ Ceramics. Journal of the American Ceramic Society, 88, 1190-1196. http://dx.doi.org/10.1111/j.1551-2916.2005.00229.x

[20] Park, H.-Y., Seo, I.-T., Choi, J.H., Nahm, S. and Lee, H.-G. (2010) Low-Temperature Sintering and Piezoelectric Properties of $\left(\mathrm{Na}_{0.5} \mathrm{~K}_{0.5}\right) \mathrm{NbO}_{5}$ Lead-Free Piezoelectric Ceramics. Journal of the American Ceramic Society, 93, 36-39. http://dx.doi.org/10.1111/j.1551-2916.2009.03359.x

[21] Park, H.-Y., Choi, J.-Y., Choi, M.-K., Cho, K.-H., Nahm, S., Lee, H.-G. and Kang, H.-W. (2008) Effect of CuO on the Sintering Temperature and Piezoelectric Properties of $\left(\mathrm{Na}_{0.5} \mathrm{~K}_{0.5}\right) \mathrm{NbO}_{3}$ Lead-Free Piezoelectric Ceramics. Journal of the American Ceramic Society, 91, 2374-2377. http://dx.doi.org/10.1111/j.1551-2916.2008.02408.x

[22] Zhou, J.-J., Cheng, L.-Q., Wang, K., Zhang, X.-W., Li, J.-F., Liu, H. and Fang, J.-F. (2014) The Phase Structure and Electric Properties of Low-Temperature Singtered (K, Na) $\mathrm{NbO}_{3}$-Based Piezoceramics Modified by CuO. Ceramics Inernational, 40, 2927-2931. http://dx.doi.org/10.1016/j.ceramint.2013.10.019

[23] Zhou, J.-J., Li, J.-F., Cheng, L.-Q., Wang, K., Zhang, X.-W. and Wang, Q.-M. (2012) Addition of Small Amounts of $\mathrm{BiFeO}_{3}$ to $(\mathrm{Li}, \mathrm{K}, \mathrm{Na})(\mathrm{Nb}, \mathrm{Ta}) \mathrm{O}_{3}$ lead-Free Ceramics: Influence on Phase Structure, Microstructure and Piezoelectric Properties. Journal of the European Ceramic Society, 32, 3575-3582.

http://dx.doi.org/10.1016/j.jeurceramsoc.2012.05.019 